\title{
The Canadian Forest Service: Agent of change in an evolving forest environment
}

\author{
by Yvan Hardy ${ }^{1}$
}

The Canadian Forest Service (CFS) has set new goals and priorities in its Strategic Plan 2003-2008, re-examining the knowledge it creates and the ways in which that knowledge is created. This is in line with the Government of Canada's pursuit of a global strategy for Canadian science and technology, supporting more collaborative international research at the frontiers of knowledge. Also, with the Canadian forest industry facing new and non-traditional competitors and repositioning its product mix, CFS is encountering increased expectations from its external partners, clients and stakeholders - as the primary forest research agency in the country and the main federal body ensuring the competitiveness of the industry. CFS is, therefore, re-defining its role as the leading player in the Canadian forest sector by re-evaluating how it does business. CFS will spearhead the development and implementation of a new national forest S\&T agenda, becoming Canada's premier source of authoritative, value-added forest information. It will also champion Canadian forest interests and expertise internationally while strengthening national consensus on Canadian forest policies and programs and advocating Canada's forest agenda within the federal government. To this end, CFS will attract and support talented personnel by creating a workplace conducive to creativity.

Key words: Strategic Plan, global S\&T strategy, non-traditional competitors, product mix, value-added forest information

Dans son plan stratégique pour 2003-2008, le Service canadien des forêts (SCF) définit de nouveaux objectifs et de nouvelles priorités. Il réexamine ainsi le savoir qu'il génère et les façons dont ce dernier est généré. Ceci correspond tout à fait aux efforts du gouvernement du Canada en vue de se doter d'une stratégie globale pour les sciences et la technologie canadiennes. Une telle stratégie a pour but d'appuyer des recherches internationales menées à la frontière du savoir et faisant de plus en plus appel à la collaboration. En outre, comme l'industrie forestière canadienne fait face à de nouveaux concurrents non traditionnels et qu'elle est en train de repositionner sa gamme de produits, les partenaires, les clients et les parties prenantes du SCF ont des attentes beaucoup plus grandes face à notre organisation, tant par rapport à son rôle d'organisme principal de recherche sur les forêts au pays qu'à celui de principale institution fédérale assurant la compétitivité de l'industrie. Par conséquent, le SCF redéfinit son rôle de joueur clé dans le domaine des forêts au Canada en réévaluant la façon dont il mène ses affaires. Il se fera le fer de lance de l'élaboration et de la mise en oeuvre d'un nouvel agenda national en matière de sciences et de technologies relatives aux forêts, devenant ainsi la plus importante source d'information sur les forêts qui fasse autorité tout en offrant une valeur ajoutée. Il défendra aussi les intérêts et l'expertise du Canada en matière de forêts sur la scène internationale tout en renforçant le consensus national sur les politiques et les programmes liés aux forêts et en défendant les priorités relatives aux forêts au sein du gouvernement fédéral. Pour ce faire, le SCF attirera et appuiera un personnel de talent en créant un milieu de travail propice à la créativité.

Mots-clés: Plan stratégique, stratégie globale pour la science et la technologie, concurrence non-traditionnelle, gamme de produits, information à valeur ajoutée sur les forêts

El Servicio Forestal Canadiense (CFS) ha establecido nuevas metas y prioridades en su Plan Estratégico 2003-2008, analizando el conocimiento que genera y las maneras en que lo genera. Estas nuevas orientaciones se insertan en el marco de la estrategia global del gobierno de Canadá para la ciencia y tecnología canadiense, apoyando investigación más cooperativa en el plano internacional a la vanguardia del conocimiento. Asimismo, dado los nuevos y no tradicionales competidores que enfrenta la industria forestal canadiense y el reposicionamiento de la combinación de estrategias de sus productos, las expectativas que los socios externos, clientes y partes interesadas ponen en el Servicio Forestal Canadiense son cada vez mayores, por tratarse del agente primario de investigación forestal en el país y del principal organismo federal encargado de asegurar que la industria forestal se mantenga competitiva. En este contexto, el CFS está en proceso de redefinir su papel como actor principal en el sector forestal canadiense, reevaluando su modo de funcionamiento. Su función será dirigir el desarrollo e implementación de una nueva agenda forestal nacional en ciencia y tecnología, pasando a ser la principal fuente de información autoritativa, de valor agregado en el ámbito forestal canadiense. También se encargará de promover internacionalmente los intereses forestales del país, su conocimiento y experiencia en el campo, fortaleciendo al mismo tiempo el consenso nacional sobre las políticas y programas del sector y fomentando la agenda forestal de Canadá en el gobierno federal. Para lograr estos objetivos, el Servicio Forestal Canadiense atraerá y dará apoyo a personal experto creando un lugar de trabajo propicio a la creatividad.

Palabras claves: Plan estratégico, estrategia global en ciencia y tecnología, competidores no tradicionales, combinación de estrategias de productos, información forestal de valor agregado

\section{Introduction}

Natural Resources Canada (NRCan) operates within a changing environment.

${ }^{1}$ Assistant Deputy Minister, Canadian Forest Service, Natural Resources Canada, Ottawa, Ontario K1A 0E4. E-mail: yhardy@nrcan.gc.ca
Internally, the Government of Canada is pursuing a global strategy for Canadian science and technology, supporting more collaborative international research at the frontiers of knowledge. As the federal agency with primary responsibility for the country's forests, the Canadian Forest Service (CFS), one of six sectors within NRCan, has 
a duty to help implement Government of Canada and departmental priorities.

Thus the CFS, in reflecting these emerging government priorities, is re-examining the knowledge it creates and the ways in which that knowledge is created.

Externally, the Canadian forest industry is facing new and nontraditional competitors and repositioning its product mix. Expectations of the CFS, both as the primary forest research agency in the country and as the main federal body to ensure the competitiveness of the Canadian forest industry, are evolving across its wide range of external partners, clients and stakeholders.

So the CFS is also re-defining its role as a player and a leader in the Canadian forest sector, re-focussing priorities and reevaluating the ways in which it does business.

The strength of the CFS is that for more than 100 years it has been built around strong leadership in scientific, research and policy capabilities. This provides a firm foundation and springboard from which to leap forward to meet the challenges and opportunities of the $21^{\text {st }}$ Century.

The CFS is doing just that. To make the most of the imperatives at hand, the CFS is spearheading development and implementation of a new national forest Science and Technology (S\&T) agenda. It is also moving higher in the value-added chain of knowledge to become more visible in its responses to crises and issues relating to Canada's forests.

Under the Canadian constitution, the provinces are responsible for the management of natural resources. When it comes to forestry, the relationship among the federal, provincial and territorial governments is guided by a framework that coordinates activities and strengthens co-operation.

The federal government carries out its responsibilities in areas such as international trade, commerce and multilateral relations, managing federal lands and Aboriginal affairs. In forest-related terms, that means the CFS role is to provide leadership in forest science and policy, working actively through various partnerships and co-operative arrangements with members of the Canadian forest community as well as members of other sectors, departments and governments.

By working closely and proactively with the other levels of government and with the broader national forest sector, the CFS will help improve forest management by building on complementary strengths, achieving economies, and ensuring that no important area of forest policy is overlooked.

Building on its track record of bringing people together on policy issues such as the National Forest Strategy and the introduction of such world-renowned initiatives as the Model Forest Program and the First Nations Forestry Program, the CFS has a unique opportunity - and responsibility - to gather the scattered yet powerful segments in this country's forest sector to become more of a leading and cohesive force in terms of innovation, research and development.

The CFS will continue to champion Canadian forest interests and expertise internationally. It will carry on its mandate to strengthen a national consensus on Canadian forest policies and programs while advocating Canada's forest agenda within the federal government. Vital to the accomplishment of all these things is an ongoing effort to attract and support talent by creating a workplace conducive to creativity.

The triple bottom line for the CFS is to see Canada's forests sustained in a manner that is socially responsible, environmentally sensitive and economically sound.

\section{Responding to a Changed Environment}

The CFS Strategic Plan 2003-2008, released earlier this year, is guiding the organization through the next five years as it moves ahead to face the challenges and opportunities of the $21^{\text {st }}$ Century. The plan distills what was learned from listening to clients, partners, staff and other interested parties; from the corporate experience of the CFS; and from

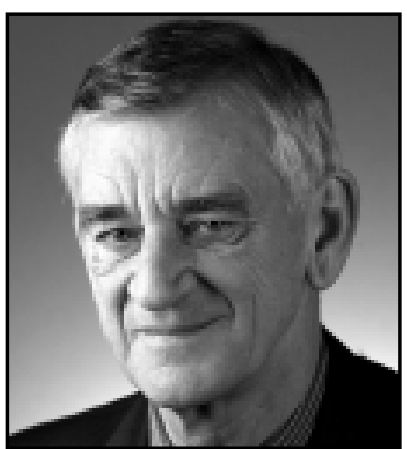

Yvan Hardy an analysis of today's environment and what is envisioned for the future.

To meet the objectives identified in the Plan, the CFS will employ a number of targeted approaches. For instance, there is a strong need for a science-based policy agency in the Canadian forest sector. As the organization best equipped by virtue of its mandate and information resources to play such a role, the CFS will align its science and policy objectives to fulfil that role. Furthermore, CFS initiatives, programs and projects are being reviewed regularly to ensure they continue to be relevant, effective and affordable.

The CFS will sharpen its S\&T strategies at the national and regional levels. For years, the agency has collaborated and partnered with other S\&T organizations. However, the concept of partnership will now take on new meaning as the CFS works with those and other partners in the development of a network of S\&T organizations conducting complementary research. Resources will be pooled and new funding pursued collaboratively, not competitively.

While continuing to generate its own data and information, the CFS will make a greater effort to move up the "value chain" by coalescing, analysing and interpreting information from many different sources. The result will be a more complete picture of Canadian forest issues and opportunities. In addition, the CFS will place more emphasis on bridging the gap between created knowledge and its application and commercialization through technology transfer.

International agreements are increasingly influential in shaping how Canada manages it own forest resources. In the years ahead, the CFS will strengthen its contribution to international discussions by bringing scientific and policy expertise to bear to present Canadian perspectives, policies and positions clearly, credibly and persuasively.

Within Canada, the CFS will work in conjunction with all levels of government as in the past, but will be more active in supplying authoritative information and advocating wellresearched positions on key issues. The CFS will work with its partners to develop these positions and will be active in ensuring that international commitments are implemented at home and abroad.

Sound information management will be integral to the success of all CFS operations and initiatives. This will be supported by a fully functional Canadian information gathering and reporting system, and by a well-developed capability to create value-added information by synthesizing and interpreting data.

Meeting these objectives will require careful planning, proper resources and continuous evaluation. The entire orga- 
nization will align itself with the new directions. The ingenuity, creativity and commitment of all employees are vital to the success of these endeavours.

\section{CFS Credentials to be an Agent of Change Historical perspective}

The CFS has come a long way from its founding in 1899 when it consisted of a staff of one surveyor and a budget of $\$ 1000$. This sector of NRCan now boasts a complement of more than 1000 scientists, technicians, policy makers, economists, managers and support staff, all dedicated to the task of maintaining and enhancing Canada's reputation as a world leader in sustainable forest management principles and practices.

This concern for our forests was a learned rather than an innate characteristic in Canada's approach to its natural surroundings. Early settlers seemed to believe that Canada's forests were infinite and self-perpetuating, allowing the vast numbers of trees that stretched as far as the eye could see to lull them into forgetting the mistakes made in their forest-depleted homelands. Intent on clearing the land for settlement, many of these newcomers regarded Canada's forest cover as an obstacle requiring removal by axe, saw and uncontrolled burning that laid waste to untold hectares of prime woodlands.

This cavalier disregard for Canada's forests persisted as the country's growing population pushed westward. It was also reflected in our early attitude toward the commercial harvesting of trees, where logging was carried out with no thought for sustainability. Adding to this exploitation of Canada's forest cover was the introduction of a national railway system in the latter half of the $19^{\text {th }}$ century where live embers from coal-fired steam locomotive engines and the careless habits of railway personnel and passengers caused the outbreak of countless forest fires.

Fortunately, there were influential Canadians both within the forest community and in the general populace who had the foresight to realize that without proper regulations, this country's forests were in grave danger. By the mid-19th century, most jurisdictions across the country had begun to pass legislation to control forest use. At the federal level, that lone surveyor, Elihu Stewart, was installed as Chief Inspector of Timber and Forestry in the newly created Dominion Forestry Branch in 1899. His efforts to promote conservation and woodland renewal through fire fighting, tree planting and forest reserves laid the groundwork for what would become the CFS of today.

\section{A century of struggle and innovative solutions}

The CFS mission of today is to promote the sustainable development of Canada's forests and the competitiveness of the Canadian forest sector for the well-being of present and future generations. This mandate has evolved from more than 100 years of peaks and valleys in the public perception of the importance of a strong federal voice for forestry. Changes in political focus, budget constraints and the slow awakening of universal awareness to the necessity for a strong, united effort to protect the world's forest heritage have all provided challenges that had to be met and overcome.

There is still work to be done. If Nature indeed abhors a vacuum, then there is an even greater role for the CFS to play both within Canada's borders and beyond in spearheading the stewardship of the earth's forest cover. What makes our organization particularly suited to this role is our enviable record of visionary research and our readiness to share the results.
One example of our ability to be at the forefront of technological opportunity goes back to the 1960s, when CFS scientists began testing formulations of a bacterial pesticide, Bacillus thuringiensis (Bt), as an alternative to synthetic chemicals. Thus, when a public outcry arose in the 1970s for chemical pesticides like DDT to be taken off the market, Bt could be made readily available.

More recently, CFS scientists have risen to the challenge of developing an effective, DNA-based diagnostic testing system to combat such pests as Scleroderris canker, Sudden Oak Death and the Brown Spruce Longhorn Beetle.

Retention harvesting as a viable alternative to clearcutting is another success story in which the CFS played a major role as part of a multi-agency co-operative, testing new approaches to harvesting and regeneration. One of the best examples of this undertaking is the Montane Alternative Silviculture Systems (MASS) project in the coastal forests of British Columbia, a joint effort involving the CFS, the B.C. Ministry of Forests, FERIC, the University of Victoria and MacMillan Bloedel (now Weyerhaeuser).

This ongoing project is studying four silvicultural treatments - clear cut, patch cut, green tree retention and shelterwoodwhere the latter three systems leave a progressively larger number of trees standing on the experimental sites. Results have already revealed feasible alternatives to clearcutting in old-growth forests and these methods have been implemented commercially.

Another CFS initiative with global ramifications is our Fire Weather Information System, first developed in 1996 for the Association of South East Asian Nations (ASEAN). A prototype based on the Canadian Forest Fire Danger System - which produces regional weather and fire-danger maps based on weather data assessed on a daily basis from the World Meteorological Organization - this unique and advanced system could some day be used around the world.

But not all CFS success stories are technology-based. Our Model Forest Program (MFP), launched in 1992 to test the practicalities of the various components of sustainable forest management in actual Canadian forest settings, has brought together diverse groups of stakeholders who now work in relative harmony where in many cases they once considered themselves adversaries.

This program spawned the International Model Forest Network, with sites established or under development in Mexico, the United States, Russia, China, Japan, Indonesia, Myanmar, Thailand, the Philippines, Argentina and Malawi.

On another front, the widely acclaimed First Nations Forestry Program is aimed at increasing Aboriginal business opportunities in forestry, thereby helping to build strong First Nations communities across Canada. The decision-making is shared by our First Nations and the Government of Canada, along with provincial and territorial governments and the forest industry. The communities operate forest-based businesses, sustainably manage their forests, call upon traditional knowledge and market Aboriginal forest products and services.

The CFS also has several initiatives underway in conjunction with the Canadian Council of Forest Ministers (CCFM). This collaboration will be elaborated on later. But briefly, one of the highlight initiatives is the National Forest Strategy, a widely acclaimed series of five-year plans for our forests, the latest of which was unveiled in May of this year. The CFS also provides the secretariat to Forest 2020, a CCFM project geared to creating additional and stable fibre supply, improving forest conservation and increasing community prosperity. 


\section{Canada's Role as a Forest Nation}

Canada has taken its place in the front ranks of the developed nations of the world and thus its workforce no longer fits within the confines of the Old Testament-inspired description: "Hewers of wood and drawers of water." However, forestry is still a major economic force in this country and Canada has a leading role to play on the world stage in sustainable forest management.

With $10 \%$ of the earth's forests within our borders, Canada accounts for over $20.5 \%$ of global trade in forest productsthe world's largest exporter of these commodities. Our forest sector contributed $\$ 34.4$ billion to Canada's balance of trade in 2001, and thus was the second leading net contributor to the country's economy. Some 353000 people and more than 300 Canadian communities directly depend on the forest industry for their livelihood.

Canada is a forest nation and, as such, has a moral as well as a practical responsibility to play both a national and an international role in the sustainability of the world's forests.

\section{Heading in the Right (Strategic) Direction}

Just as the world's forests continue to evolve and adapt to changing global conditions, so must any organization charged with the responsibility of being the wise overseer of our natural resources be prepared to amend and update its operational plans in order to reflect realities and fulfil its mandate.

The CFS continuously monitors its priorities, policies and programs for relevance and worthiness. And, at five-year intervals, the organization formally examines the path it is on and the strategic directions it wishes to take in the near future.

The CFS Strategic Plan 2003-2008 will guide the organization through the issues, challenges and opportunities of the next half-decade. The principles articulated in the plan are:

\section{Spearheading the development and implementation of a new national forest $S \& T$ agenda}

The emergence of the knowledge-based economy and a recognition of the importance of innovation to Canada's economic and social well-being have underlined the relevance of sound science as the key to forest-related policy formulation and a foundation for forest resource management.

As a federal agency, the CFS must focus its S\&T capacity to respond to emerging challenges and opportunities in public policy, stewardship and the economy. It is particularly important that the CFS ensures the effective use of S\&T in government decision-making related to forests.

Central to these tasks is the conducting of world-class, high-impact research. This has been a CFS priority throughout its history but it is a current fact of life that governments and the private sector have faced downsizing and diminishing resources. Given that environment, we all have had to sharpen our pencils to make sure that we get the most out of the resources we have available. We must find the niches where our research can be most effective and work with partners to eliminate overlap and gaps.

Another CFS priority is providing guidance for strategic national investments in forest S\&T. By the time this is being read, the results of consultations among CFS and other high-level decision-makers such as the CEOs of forest companies, the Forest Products Association of Canada, the deans of Canadian universities and the granting councils to come up with a new model for funding research on national priorities should be known and implementation could already be under way.

To be the recognized voice of the Canadian forest community, it is necessary to continue to build excellence in forest research capacity for the future. We are doing this not only by attracting highly qualified and motivated personnel to our ranks but also by working in partnership with others. Two prime examples of this effort are our involvement in providing scholarships, internships and guidance to students through the Natural Sciences Engineering Research Council (NSERC) and the Social Sciences and Humanities Research Council (SSHRC).

Tighter funding also impacts on our ability to maintain the high profile necessary to keep forestry and forest issues in the minds of the policy and decision-makers. This means that we have to work that much harder to keep our image at a high level. From time to time, problematic issues arise that have the side effect of making our efforts better known. For instance, the recent successful battle against the infestation of the Brown Spruce Longhorn Beetle in Halifax put the CFS in the forefront of a situation that attracted considerable attention both domestically and internationally. Our scientists figured prominently in public discussions and media reports of the problem and were credited with playing a key role in its resolution. Such instances are a mixed blessing at best.

S\&T must be integrated into the development of government policies and the modification of existing ones. The inherent difficulty has been that policy makers tend to want immediate answers to the issues at hand and research can often be long-term. But a concerted effort is underway to bridge the gap between the two equally important entities.

There has been criticism in the past from some who could not see the value of our research and were unaware of how our work results benefited them - even though they were probably using the results in their everyday operations - $\mathrm{Bt}$, fire management tools, and so on. This lack of recognition for our efforts has been mitigated to an appreciable extent by an undertaking on our part to work closely with senior level people to make sure they know who we are, what we are capable of doing and what we are accomplishing. We intend to step up our efforts in this regard through staff exchanges and the pooling of our people with others from industry and universities to create both a synergy of effort and a closer working relationship that will foster a climate of increased understanding and co-operation.

\section{Becoming Canada's premier source of authoritative, value-added forest information}

We are also developing ways to assist resource managers with the uptake and application of new knowledge and systems.

As Canada's national forestry agency, the CFS is uniquely mandated to develop and maintain a technically and scientifically rigorous information base on our forests and the forest sector. This information is crucial in identifying issues of national and international interest and supporting the development of relevant and effective public policy.

In addition, working with partners, the CFS contributes scientific and technical capacity and knowledge to address the information needs of forest managers and policy makers in the private and public sectors across Canada. Credible, timely forest information is essential to our forest sector, and specifically to the industry in demonstrating to the world and its markets 
our economically viable, environmentally responsible and socially acceptable forestry practices.

Given that forest sector information is neither organized nor resident in any single data bank, a key challenge in the management of information and knowledge is the development of strategic partnerships. The nature of these co-operative efforts will vary-with national partnership models operating on national files such as Climate Change, Biodiversity, Criteria and Indicators and Market Access and more local partnerships responding to land-based information needs.

Traditionally, the CFS has been good at creating knowledge. It is one of the things we do best-create knowledge and publish it in scientific journals. Now, however, we are viewing knowledge as an asset to be managed. We are transforming an organization of intelligent people into an intelligent organization, while making sure that we retain those intelligent people.

That is knowledge management - applying the knowledge we have created and archived by turning it into an intellectual commodity that our client organizations can use.

We are reorganizing our knowledge to allow better access to it. Those who seek to make use of this material want to be able to find information on a given subject as quickly and effortlessly as possible.

On the other side of the coin, how we collect and report on the data that form the raw material for knowledge management is a delicate and sensitive issue. We have the dual responsibilities of protecting the proprietary rights of those from whom we collect this information - be they our provincial and territorial counterparts or components of the forest industry-and safeguarding the information we synthesize into knowledge to keep our competitive edge against offshore competitors. The National Forest Information System currently under development is designed to incorporate these requirements for forest managers and stewards across Canada to help them meet new challenges as they arise.

By managing knowledge wisely, the CFS can assist the forest community in being more competitive in a global economy. For instance, with this knowledge, Canadian industry will be able to demonstrate clearly to the world that it is managing our forest resources in a sustainable manner in a marketplace that is becoming increasingly aware, increasingly vocal and increasingly demanding that the forested nations be wise and judicious custodians of their natural resources. It will also allow decisionmakers to enact policy faster and from a broader information base and will add decision support capability for communities to assist them in ensuring stability and sustainability.

\section{Championing Canadian forest interests and expertise internationally}

To use the vernacular, when it comes to safeguarding the Canadian forest community's international marketing opportunities, you have to be in it to win it. CFS personnel, in co-operation with representatives of the Department of Foreign Affairs and International Trade (DFAIT), other federal agencies and the Canadian forest industry, will continue to play an active role both in promoting Canadian forest products internationally and in keeping a watching brief on the regulatory activities of other countries for signs of potential threats to the market penetration of Canadian wood and wood products.

These international objectives are met, and will continue to be met, through participation in bilateral and multilateral fora, memberships in international organizations, participation in forest-related conferences and the formulation of S\&T partnerships that position Canada as a global leader in sustainable forest management.

In addition to developing new markets, the international agenda of the CFS is geared to preventing and/or eliminating arbitrary barriers that, by accident or design, could hamper the competitiveness of Canadian trade in forest products.

Such market-restricting action can take a number of forms. For instance, a country's building code standards might specify the use of wood in sizes, colours or species not consistent with Canadian products - as opposed to the material's inherent strength characteristics. If and when we see building code standards that we feel unfairly exclude exports from Canada, we will intervene- taking the issue to the World Trade Organization if necessary.

There are also phytosanitary issues that have to be dealt with For instance, we have certain insects in Canada that Europe does not have and vice versa. As globalization increases, so too does the concern over invasive species. We will continue to work and negotiate for fair and reasonable regulations to permit the import and export of sufficiently sanitized lumber. Otherwise, some countries could, through indirect means, erect barriers that would have a negative effect on Canada's forest community by blocking trade or making it prohibitively expensive.

Another issue deals with the evolution of certification regulations that could lead to policies that discriminate against Canadian wood exports. If, for example, a country were leaning toward the adoption of only one of the three certification systems Canadian companies have the option of selecting, we would intervene on such an initiative. Since there is no evidence suggesting one system is more effective than another in promoting sustainability, it comes down to an assessment by individual companies as to what is best for them. Should a foreign government target only one system, we would consider this inappropriate ecolabelling.

In many instances, there is a muddying of the waters of environmental policy and trade policy. That is why the CFS will continue to be on constant alert for signs of discriminatory regulations that would harm Canada's forest export potential.

Whether foreign lawmakers do it intentionally or by oversight, policy positions can be based on scientific studies that we find flawed or disagree with for other legitimate reasons. With the benefit of CFS research, we can use our science to champion Canadian interests and challenge potential legislation based on inconclusive or misleading scientific evidence, thus giving Canadian forest products a better chance of being accepted.

Canada spends much time and effort in international processes. By being there to provide input, we can have a positive influence on decisions that might otherwise adversely affect us in the marketplace. Our involvement also shows other countries that we are fulfilling our responsibilities as good forest stewards by practising sustainability and by both keeping up with and in some areas leading the charge in evolutionary forest management.

And on the subject of international marketing, a five-year, \$35 million Canada Wood Export Program (Canada Wood) was announced in May 2002. Using this cost-shared program, NRCan is working with regional and national wood product associations, the provinces and the forest industry to diversify Canada's exports to offshore markets. Canada Wood's mandate is to explore and expand new market opportunities and 
seek to brand Canada as a preferred and dependable supplier of quality wood products. The focus of the program is on the promotion of generic wood products and manufactured housing. A main thrust of this initiative is into the marketplace of China, where wood is not a traditional building material.

\section{Strengthening national consensus on Canadian forest policies and programs}

The CFS will continue to pursue the development and implementation of coherent national forest policies and programs based on the best scientific information available to maintain a balance among economic, social and environmental values across the country.

The creation of the Canadian Council of Forest Ministers (CCFM) in 1985 has provided an important forum for the two senior levels of government to work co-operatively in addressing major issues of common interest. As outlined in the CCFM Framework for Co-operation in Forestry, the federal and provincial/territorial governments share responsibilities in areas of S\&T, industry and regional development, and the environment.

This CCFM partnership has resulted in many significant policy initiatives. One of these is Forest 2020, which promotes the establishment of fast-growing, high-yield plantations as a new fibre supply. This initiative, by increasing carbon sequestration, will aid Canada in its commitment to the Kyoto Protocol to reduce greenhouse gas emissions (GHG) by six percent below 1990 levels between the period of 2008 and 2012.

The CCFM in conjunction with the National Forest Strategy Coalition (NFSC) - comprised of a cross-section of forest stakeholders representing the full spectrum of interestshas been instrumental in the development of a national forest strategy - the fifth since NFSC's founding-focussed on sustainable development where economic, environmental, social and even cultural imperatives are addressed. The latest strategy was unveiled in May of this year at the National Forest Congress in Ottawa.

No talk of partnerships and consensus would be complete without underlining the importance of the earlier-mentioned and highly successful Model Forest Program launched by the CFS almost a dozen years ago. This program usually takes place in or near small, rural, forest-dependent communities and creates local solutions to the issues and challenges surrounding sustainable forest management. The MFP is an inclusive program that avoids a top-down approach and opts for a harmonious atmosphere where diverse groups and individuals may not share the same perspective on forest-related matters, but respect each other's right to hold and express their own opinions in working toward consensus.

Many CFS partnership efforts have been highly successful, but there is still room for improvement. Our municipalities sometimes get lost in the shuffle in forest-related matters and emphasis must be put on helping them build their capacity and diversification so that they are less vulnerable to economic shifts and downturns.

While we have a good track record in discussing common issues with stakeholders in such areas as wildlife, endangered species, fisheries, ecoculture and parks, we anticipate opening up or amplifying current dialogues with those federal agencies and NGOs involved in agriculture and other natural resources. By partnering with all factions involved in the stewardship of our landscape, we will build synergies that will strengthen our mandate in sustainable forest management.

\section{Advocating Canada's forest agenda within the federal government}

One definition of public relations is: "Doing a good job and getting credit for it." An economic fact of life-especially in an age where so many worthwhile causes vie with each other for attention - is that the key decision-makers must be kept aware of an agency's accomplishments and its requirements for the future. We at the CFS believe we do good work-and we have received many accolades from the domestic and international forest community attesting to this. But that is only one part of the equation. It is equally important that our reputation and stature be well understood by those decision makers who may be on the outside of the forest sector circle.

To be successful in maintaining and enhancing our role as the primary advocate for forestry and the forest sector in Canada, the CFS must be able to influence federal policy development as it relates to Canadian forestry.

We will therefore champion forest interests with other federal departments and agencies whose policies and programs relate to the viability of the sector. Fortunately, we can build on a solid foundation of past and current successes. But build we must. Our architects and engineers will be the CFS personnel who have been and will become key participants on committees and initiatives that advance the forest sector. We shall continue to be key participants in interdepartmental and intergovernmental policy and program processes and initiatives.

Forestry is a vital thread helping to hold together the social, environmental and economic mosaic of this country. We know this as an irrefutable fact. Our task is to continue to drive home this message through the proper channels at every opportunity.

\section{Attracting and supporting talent by creating a work- place conducive to creativity}

The CFS recognizes its responsibility to provide state of the art facilities, equipment and core expertise required to meet priority program needs. We intend to become an incubator for research, innovation, training and commercialization in co-operation with other NRCan sectors, federal, provincial and municipal agencies, academia, industry and other forest stakeholders. The object of these initiatives is for the CFS to become recognized as the "Workplace of Choice" in the pursuit of forest research and, both nationally and internationally, as the logical location for visiting scientists and post-graduate research in forestry and related disciplines.

One example of our intentions in this area is the "Science Works" campus we are currently assembling at the Great Lakes Forestry Centre in Sault Ste. Marie. Our facilities and those of the Ontario Forest Research Institute are on neighbouring properties and we have always had good scientist-to-scientist interaction between the two. We are now negotiating with our provincial colleagues to foster increased co-operation on a corporate to corporate level.

We see these two facilities as being the anchors in a "science shopping mall" that can enhance R\&D through the continual growth of partnerships.

Paramount to the success of these and other initiatives is a CFS workforce that reflects a culture of continuous quality 
improvements to facilitate program delivery. This can only be achieved by making the CFS a model organization for employee diversity, respect, dedication and excellence.

The CFS will promote and support a culture of innovation, entrepreneurship and continuous improvement at all levels of the organization. It will foster the ability to develop solutions to priority issues faced by the forest sector and to capitalize on opportunities in a rapidly changing environment. Other goals will include the acceleration of technology transfer and knowledge dissemination and maximizing the impact of CFS programs and projects.

The necessary competencies to meet future mandates, roles and directions of the CFS will be determined and developed through the identification of organizational skill sets related to CFS strategic plans required to move the organization forward.

We will promote an inclusive, stimulating and engaging work environment where employees have a sense of contribution and recognition. Attraction and retention strategies will be developed to effectively position the CFS to respond to human resource needs created by a growing competition for scarce human and financial resources. Another important element of this attraction and retention plan is to develop appropriate reward mechanisms such as developmental or long-term training awards to promote employee well-being and foster excellence.

\section{Conclusion}

With a new millennium barely out of the starting blocks, the CFS has a singular opportunity to be an agent for change within the forest sector both domestically and internationally.
We have learned a great deal in our 100+ years of existence, we have accomplished much and we stand on the threshold of even greater accomplishments in the future.

As the rallying force behind the various factions making up the Canadian forest community, the CFS has a vital and exciting role to play in seeing that the policy and decision makersboth within our own government and forest community and amongst governments, stakeholders and product buyers worldwide-recognize our organization as a global leader in the realm of sustainable forest management.

First-year Philosophy students ask each other the hypothetical question: "If a tree falls in the forest and there is no one there to hear it, does it make a sound?" One important lesson we have learned over the years is that every tree that falls in our forests has the potential, figuratively, of making a sound that reverberates far and wide. The world is becoming increasingly aware of the need for responsible management of our forests and we must retain and enhance our global reputation as wise custodians of this natural resource.

We have also become acutely aware that our greatest ally is synergy - the coming together of all those involved in and affected by our forest policies and practices in a united effort to make certain that the precious legacy we have inherited from our ancestors is available and thriving for those who come after us.

Partnerships-to put a positive twist on an old expression-are stable ships that will help us steer a course toward sustainability as we face the issues, challenges and opportunities of forest management in the $21^{\text {st }}$ century. 